\title{
Epiphytic and regulated microbial contaminants of food vegetable raw materials and products
}

\author{
Inna Pylypenko, Liudmyla Pylypenko, Elena Sevastyanova, \\ Evgeniy Kotlyar, Ruslana Kruchek
}

\author{
Odesa National Academy of Food Technologies, Odesa, Ukraine
}

\section{Keywords:}

Epiphyte

Microorganism

Vegetable

Canning

Patulin

\section{Article history:}

Received 15.04.2016

Received in revised form 18.06.2016

Accepted 30.06.2016

\section{Corresponding author:}

Liudmyla Pylypenko E-mail:

1.pylypenko@mail.ru

\begin{abstract}
Introduction. Biological hazards as priorities at the evaluating degree of risk are caused by the presence of microorganisms in food products.
\end{abstract}

Materials and methods. As objects of study common types of fruits, vegetables and berries were used. Conventional microbiological techniques such as mesophylic aerobic and optional anaerobic bacteria were used, fungi and yeasts have been considered by inoculation under beef-extract agar (MPA) and word agar, respectively, coliforms was determined by inoculation in liquid culture media, Bacillus cereus and Clostridium perfringens was determined by ISO methods, the last with pre-treatment developed.

Results and discussion. Group composition of epiphytic microorganisms, which contaminated widespread types of fruits, vegetables, berries on indices of mesophylic aerobic and optionallyanaerobic microorganisms, mold fungi, yeasts, coliforms (BGEC), clostridia were studied. The considerable contamination of raw materials by mesophylic bacilli from $1,8 \cdot 10^{2}$ to $7,6 \cdot 10^{8} \mathrm{CFU} / \mathrm{g}$ was established. It was shown, that the main isolated morphotypes of bacilli can be ascribed to of subtilis-licheniformis group. The composition of vegetable raw materials microorganisms gives an indication of both the possibility of epidemiological risk and product high quality. Contrary to previous opinion about the dominance among epiphytic microbiota of fungi, our in some cases showed preprintiat content of rod-shaped microorganisms. Grown and picked in the same fruits of different varieties are distinguished in the predominant species of fungi. The concentration of patulin, depending on the degree of spoilage of fruits, was determined by priority method which we have developed. A large number of soil microorganisms, including Bacillus and Clostridium, are on the surface of the plant material, especially root vegetables. According to the studies, the probability of detecting dangerous to human Clostridium perfringens on the leaves of green plants is up to $61 \%$, on vegetables - up to $39 \%$. Subtilis-licheniformis microorganisms are the dominant raw materials contaminants and prevail in the composition of microbiota of product before sterilization. They were also detected in the residual microbiota of finished canning. The food poisoning agents were detected from plant raw materials among isolated bacteria - Bacillus cereus and others. Bacillus cereus was found in $6.2 \%$ of the investigated samples of fruits, $33 \%$ of samples of carrot, $21 \%$ of samples of parsley, and up to $9.5 \%$ of the samples of canned food.

Conclusions. High thermostability of spore- forming microorganisms of raw materials, including the test-cultures, was shown. This may account for their presence in canned products, cause deterioration of the organoleptic properties of foods and toxic effects on the human organism. 


\section{Introduction}

The document CAC/GL 21 by the Codex Alimentarius, other directive documents of the EU (e.g. the report by the EU Commission «On the Strategy of the Microbiological Criteria Choice for Food Products in the Food Legislation of the EU», the leading document of the EU 2073 «On Microbiological Criteria for Foodstuffs»), and the leading documents of Food Drug Administration (the USA), provide with the general considerations concerning the principles of development and application of the microbiological criteria for the different types of food products. The Codex Alimentarius commission has developed the safety-control measures of food products, including biological safety according to the document CAC/GL 69. Evaluation of food safety in modern conditions is relevant throughout the world, including Ukraine. This is confirmed by the documents cited, as well as the Law of Ukraine"On safety and quality of food" and other government acts and regulations, modern conditions of food safety assessment and food quality are particularly relevant.

Ukraine, by it's soil-climatic conditions, is similar to some foreign countries, thus the presented investigation for Ukrainian regions may be topical for other countries. The problem of safety as the most important characteristics of nutrition quality is becoming increasingly important due to the increasing pollution of the environment. And that leads to a permanent increase in the contamination of food raw materials and food products with biological agents and chemicals that affect human health [1-3].

In the food industry a number of microorganisms is used to provide necessary consumer properties of food or increase their shelf life. But the presence of certain other microorganisms has to be strictly controlled and in the raw materials processing to ensure restriction of their number, or the impossibility of their development. The latter include pathogens of such nutritional diseases as food poisoning or food infection. The former are caused by toxins of microorganisms developing in a food product, the later are infectious diseases, in which the food product serves only as an intermediary in the transmission of pathogens, claiming the lives of more than 1.8 million children each year. According to statistical data of annual economic losses, due to diseases, caused by multiple pathogenic microorganisms, constitutes up to 35 US billion dollars in the USA, in Australia to 2.6 billion Australian dollars, and social losses are irreplaceable [2, 4, 5].

Biological hazards as priorities at the evaluating degree of risk are caused by the presence of such microorganisms in food products as helminthes and protozoa, and insects (venomous or transmitting). The reason for rising of biological in nature dangers is a modern fashion for consumption of raw or minimally processed foods culinary, increasing the products proportion in diet, improperly cooked or stored for a long time, and the use of new types of food raw materials, made possible by the expansion of international trade [6 $10]$.

Currently the bacteria become a source of food poisoning and infections are in the focus of attention of hygienists. These microorganisms are the kind Salmonella, Clostridium botulinum, Clostridium perfringens, Staphylococcus aureus, Bacillus cereus, Campilobacter jejuni, Yersinia enterocolitica and Yersinia pseudotuberculosis, Listeria monocytogenes, Vibrio cholerae $\mathrm{O}$ and non-O-1, Vibrio parahaemolyticus, Vibrio vulnificus genera and other representatives of the Vibrio, Shigella, Streptococcus genera, Aeromonas hidrophila, Plesiomonas shigelloides, group of Gram-negative bacteria Miscellaneous enterics, and Escherichia coli [10-13]. Such viruses as the Hepatitis (A and E) virus, Rotavirus, Norvalk virus and others and parasites - helminthes and intestinal 
pathogenic protozoa, the source of which may be water, shellfish, sick animals and people can also contribute their share of the risk of nutritional diseases.

Our own analytical review made it possible to investigate the morphological characteristics and specific cultural features of the growth of these microbial contaminants of food products on nutrient media. Given that the plant products, that are quantitatively dominant in the human diet, the experimental study on the qualitative and quantitative composition of the group of epiphytic microbiota group, the main most common types of juicy vegetable raw materials was conducted.

Aim of the researches was a study of qualitative and quantitative composition of microbial contaminants of vegetable raw materials and some products of its processing, their features and potential danger for a consumer.

\section{Materials and methods}

As objects of study common types of fruits, vegetables and berries were used. We studied the following species and varieties of vegetable raw materials: 4 apple varieties Renet Simirenko var. apples (Odesa`s and Poltava`s regions), Antonovka var. apples, Jonatan var. apples and low-grade apples (Odesa`s region), 2 varieties of pears - Bergamot var. pears and low-grade pears (Odesa`s and Poltava`s regions), 2 varieties of carrot Nantski var. carrot and low-grade carrot (Odesa`s and Poltava`s regions), raspberries (Odesa`s and Poltava's regions), sweet pepper, green pea, lettuce var. Khutchiryavitz Odesskiy, leaf parsley, cucumbers (Odesa's region); raspberry with and without peduncles, raspberries and strawberries of different maturity.

Conventional microbiological techniques were used: such as mesophylic aerobic and optional anaerobic bacteria (MAFAnM) have been considered by inoculation under beefextract agar (BEA) ISO 4833-2:2013, fungi and yeasts was measured by wort agar ISO 13681:1995, ISO 21527-1:2008. Coliforms were determined by inoculation in liquid culture media by ISO 16649-2:2001, ISO 21528-2:2004, and Bacillus cereus was determined according to ISO 7932:2004. Clostridium perfringens have been considered by ISO 7937:2004 and in accordance with the method developed from the sample of microorganisms separated biomass primary cells by centrifugation at 1,500xg for 2 minutes and the supernatant filtered through nitrocellulose membrane filters of 0.22 micron diameter (Millipore) or 7,500xg centrifuged at for 10 minutes [14].

\section{Results and discussion}

Contaminants of fruits and vegetables were represented as typical and casual types of microorganisms that fall out from the soil, water, rainfall, wind-blown, birds, rodents, insects, and with the technological processing - also equipment, containers, vehicles, arms and clothing of workers and other objects.

The main source of contamination of vegetable raw materials is the soil, in $1 \mathrm{~g}$ which microbial quantity can range from 1 to 4 billion cells at a fairly high numbers of bacterial spores from a few thousands to several millions.

The information about microbial contamination and most widespread types of microorganisms in vegetable raw materials is given in Table 1. 
Table 1

Microbiological description of fruits and vegetables raw materials going into processing and storage, (CFU/G)

\begin{tabular}{|l|c|c|c|c|}
\hline \multirow{2}{*}{ Type of raw materials } & Mold fungi & Yeasts & \multicolumn{2}{|c|}{ Bacteria } \\
\cline { 4 - 5 } & & & $\begin{array}{c}\text { mesophylic } \\
\text { bacteria }\end{array}$ & coliforms \\
\hline $\begin{array}{l}\text { The Renet Simirenko var. } \\
\text { apples (Odesa`s region) }\end{array}$ & 69 & $2,7 \cdot 10^{2}$ & $1,8 \cdot 10^{2}$ & 7 \\
\hline $\begin{array}{l}\text { The Renet Simirenko var. } \\
\text { apples (Poltava`s region) }\end{array}$ & $1,1 \cdot 10^{2}$ & $2,0 \cdot 10^{2}$ & $1,6 \cdot 10^{2}$ & 2 \\
\hline $\begin{array}{l}\text { The Antonovka var. } \\
\text { apples }\end{array}$ & 81 & $2,5 \cdot 10^{2}$ & $3,9 \cdot 10^{2}$ & 5 \\
\hline The low-grade apples & 101 & $3,2 \cdot 10^{2}$ & $4,3 \cdot 10^{2}$ & 15 \\
\hline The Bergamot var. pears & $1,2 \cdot 10^{2}$ & $3,5 \cdot 10^{2}$ & $7,4 \cdot 10^{4}$ & 3 \\
\hline The low-grade pears & $7,2 \cdot 10^{2}$ & $5,0 \cdot 10^{3}$ & $7,9 \cdot 10^{4}$ & 2 \\
\hline Sweet pepper & $2,4 \cdot 10^{2}$ & $9,8 \cdot 10^{5}$ & $6,5 \cdot 10^{6}$ & 4 \\
\hline Green pea & $2,8 \cdot 10^{2}$ & $8,7 \cdot 10^{5}$ & $6,1 \cdot 10^{6}$ & 6 \\
\hline The Nantski var. carrot & $9,4 \cdot 10^{4}$ & $3,2 \cdot 10^{5}$ & $9,2 \cdot 10^{7}$ & $1,9 \cdot 10^{3}$ \\
\hline The low-grade carrot & $8,9 \cdot 10^{4}$ & $4,1 \cdot 10^{5}$ & $7,6 \cdot 10^{8}$ & $2,9 \cdot 10^{3}$ \\
\hline $\begin{array}{l}\text { Lettuce var. } \\
\text { Khutchiryavitz Odesskiy }\end{array}$ & $3,1 \cdot 10^{3}$ & $4,0 \cdot 10^{2}$ & $6,7 \cdot 10^{7}$ & 51 \\
\hline Leaf parsley & $5,8 \cdot 10^{3}$ & $7,9 \cdot 10^{2}$ & $9,4 \cdot 10^{6}$ & 48 \\
\hline Cucumbers & $1,8 \cdot 10^{2}$ & $9,2 \cdot 10^{2}$ & $1,4 \cdot 10^{5}$ & 37 \\
\hline
\end{tabular}

As it seen from the presented results, the dominating epiphytic microbiota group of vegetables and fruits studied are the bacteria. On vegetables are commonly occurred microorganisms of Bacillus, Paenibacillus, Lactobacillus, Micrococcus and Alcaligenes genera, and also then molds, among which the most typical representatives are Penicillium, Fusarium, Alternaria, Botrytis, Sclerotinia, Risoctonia. The surface of cucumbers, tomatoes and leaf vegetables is also the habitation zone of lactobacilli.

The special interest presents the berry's raw materials, which have comparatively delicate consistence, can cozily be traumatized, in consequence of which the epiphytic microbiota begins more actively develop (Table 2).

The qualitative composition of vegetable raw materials microorganisms gives an indication of both the possibility of epidemiological risk and product high quality. Contrary to previous opinion about the dominance among epiphytic microbiota of fungi, our results in some cases showed pre-printiat content of rod-shaped microorganisms.

Grown and picked in the same fruits of different varieties are distinguished in the predominant species of fungi. For example, on the surface Antonovka variety apples there are in average fungi of the such genera as Alternaria - 61\%, Mucor - $10 \%$, Fusarium $9 \%$, of other species $-20 \%$. Whereas, the Rennet Simirenko variety apples have fungi of the such genera as Penicillium (57\%), Aspergillus (23\%), other 20\%, in average, the Jonatan variety apples have Aspergillus fungi (58\%) (Figure 1). 
Table 2

Microbiological description of berry raw materials going into processing and storage

\begin{tabular}{|l|c|c|c|c|}
\hline \multirow{2}{*}{ Type of raw materials } & \multirow{2}{*}{$\begin{array}{l}\text { Mold } \\
\text { fungi }\end{array}$} & \multirow{2}{*}{ Yeasts } & \multicolumn{2}{|c|}{ Bacteria } \\
\cline { 4 - 5 } & & $\begin{array}{c}\text { mesophylic } \\
\text { bacteria }\end{array}$ & coliforms \\
\hline $\begin{array}{l}\text { The raspberry without peduncles, } \\
\text { CFU/G }\end{array}$ & $2,7 \cdot 10^{3}$ & $9,9 \cdot 10^{4}$ & $6,4 \cdot 10^{3}$ & 102 \\
\hline $\begin{array}{l}\text { The raspberry with peduncles, } \\
\text { CFU/G }\end{array}$ & $3,3 \cdot 10^{2}$ & $2,4 \cdot 10^{4}$ & $7,9 \cdot 10^{2}$ & 12 \\
\hline $\begin{array}{l}\text { The raspberry of picking } \\
\text { maturity, \% }\end{array}$ & 10,6 & 86,2 & 3,2 & 0,09 \\
\hline $\begin{array}{l}\text { The raspberries of technical } \\
\text { maturity, \% }\end{array}$ & 2,5 & 92,1 & 5,4 & 0,005 \\
\hline The raspberry of overmatured, \% & 1,7 & 96,3 & 2,0 & 0,001 \\
\hline $\begin{array}{l}\text { The strawberry of technical } \\
\text { maturity, CFU/G }\end{array}$ & $1,8 \cdot 10^{2}$ & $4,3 \cdot 10^{3}$ & $3,9 \cdot 10^{2}$ & 35 \\
\hline $\begin{array}{l}\text { The strawberry of technical } \\
\text { maturity, \% }\end{array}$ & 3,4 & 87,9 & 8,0 & 0,7 \\
\hline The strawberry of overmatured, \% & 5,3 & 90,3 & 4,2 & 0,2 \\
\hline
\end{tabular}

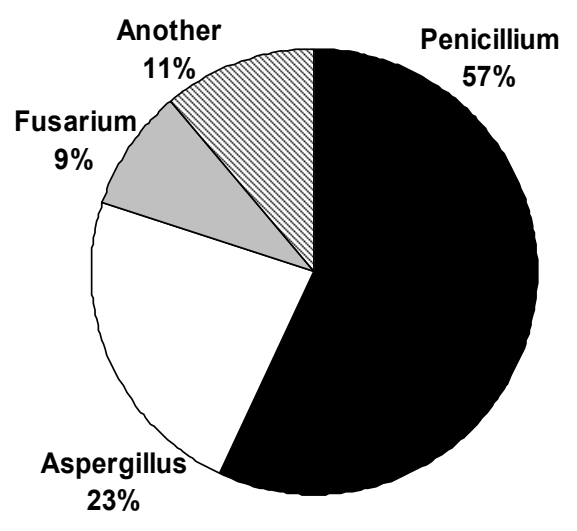

Rennet Simirenko variety apples

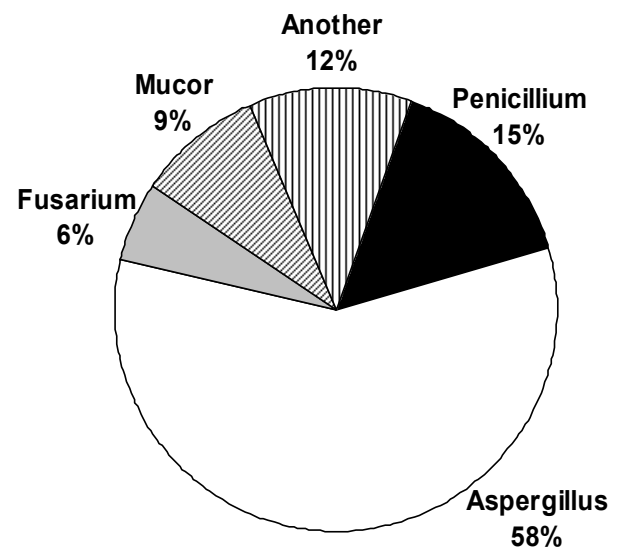

Jonatan variety apples

Figure 1. The group composition of fungi-epiphytes of apples

The comparative evaluation of contamination of raw materials from a variety of soil and climatic regions of microorganisms is shown in Figure 2. 


\section{- Food technologies-}

The following fungi are capable of producing hazardous mycotoxins: Penicillium patulum, Penicillium expansum, Penicillium urticae, Penicillium rugulosum, Aspergillus clavatus, Aspergillus flavus, Aspergillus parasiticus, Fusarium solani, Fusarium nivale, Fusarium circinatum, etc. $[5,15,16]$.

There are the methods for biological testing of toxic substances including the use of Daphnia magna $S$. in a variety of objects known $[7,17,18]$. The following Table 3 presents the results of patulin determination method which we have developed by using Daphnia magna $S$. [7] in tomato samples.

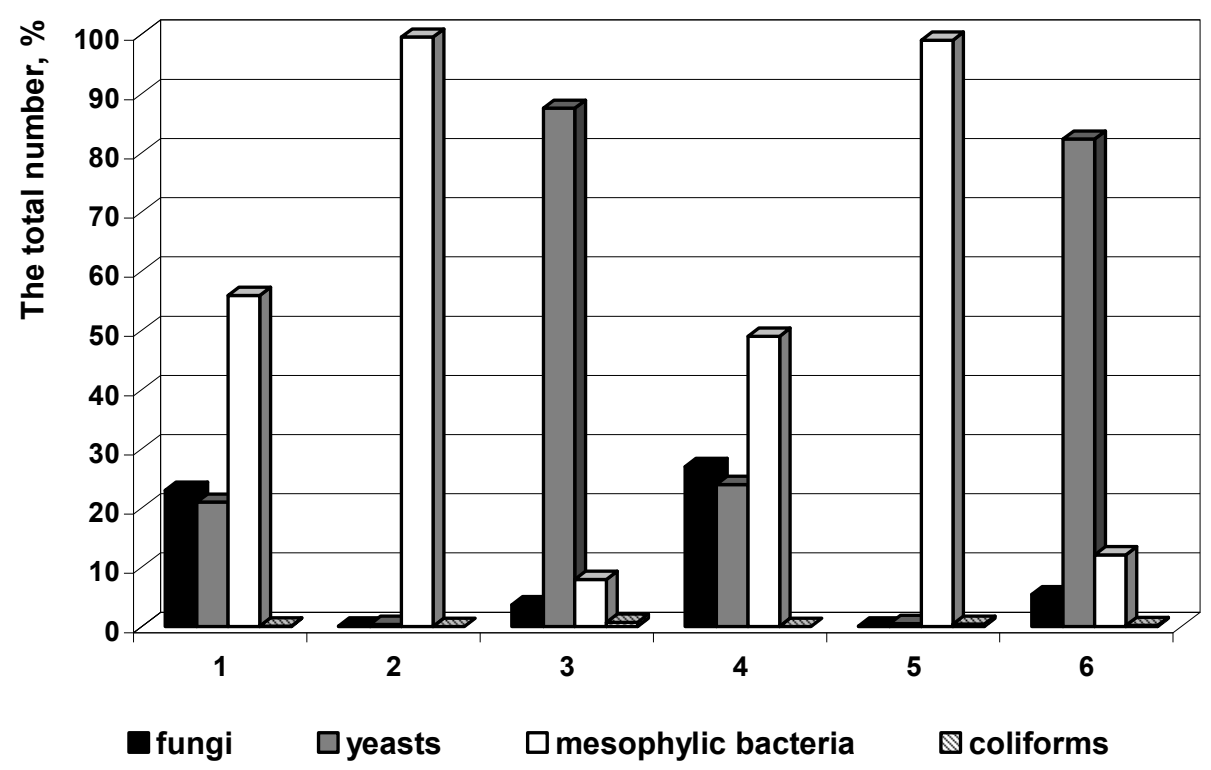

Figure 2. The microbial contaminants in raw materials:

1 - pears, Odesa`s region; 2 - carrot, Odesa`s region;

3 - strawberry, Odesa`s region; 4 - pears, Poltava`s region;

5 - carrot, Poltava`s region; 6 - strawberry, Poltava`s region

The influence degree fruits spoilage on patulin accumulation

Table 3

\begin{tabular}{|c|c|c|}
\hline Samples & $\begin{array}{c}\text { Approximate level of fruits destruction, } \\
\text { \% from total square }\end{array}$ & $\begin{array}{c}\text { Patulin concentration, } \\
\boldsymbol{\mu} / \mathbf{k g}\end{array}$ \\
\hline 1 & 0 (without visible defects) & 0,1 \\
\hline 2 & 10 & 100 \\
\hline 3 & 30 & 400 \\
\hline 4 & 50 & 800 \\
\hline 5 & 100 & 1800 \\
\hline
\end{tabular}


As a result of investigation of juicy vegetable raw materials, the comparative numerical ratio of fungi, yeast, MAFAnM and coliforms as a part of epiphytic microflora of apples, grapes, peppers, carrots, and strawberry were found. Compared with other fruits the lowest number of microorganisms has been detected on the surface of apples. This can be explained by the presence of waxy coating on the surface of apples, which prevents microorganisms feeding. In some cases, the yeast on the surface of the berries dominates. A large number of microbial cells distinguish vegetables from fruits and berries.

A large number of soil microorganisms, including Bacillus and Clostridium, are on the surface of the plant material, especially root vegetables. According to the studies, the probability of detecting dangerous to human Clostridium perfringens on the leaves of green plants horse radish is up to $61 \%$, on vegetables - up to $34 \%$, based on the results of our study - up to $39 \%$.

Subtilis-licheniformis microorganisms are the dominant raw materials contaminants and prevail in the composition of residual microbiota of product before sterilization. They were also detected in the residual microbiota of finished canning. The presence of aerobic bacillus does not always cause a significant change in the organoleptic properties of canned products. In some countries Bacillus subtilis are used as probiotics.However, analysis of the literature suggests the presence among them of microorganisms with toxigenic properties even in acceptable residual canned microbiota, which may lead to reduced immunity and cause various diseases in humans [19-21]. According to the information in Table 4, their high thermal stability contributes to their survival after technological processing of raw materials.

Table 4

Indices of the thermal stability of test organisms in phosphate buffer solution

\begin{tabular}{|l|c|c|c|c|}
\hline \multirow{2}{*}{ Test organisms } & \multirow{2}{*}{$\mathbf{p H}$} & \multirow{2}{*}{$\begin{array}{c}\text { Tempera- } \\
\text { ture, }{ }^{\circ} \mathbf{C}\end{array}$} & \multicolumn{2}{c|}{$\begin{array}{c}\text { Thermal stability } \\
\text { indices }\end{array}$} \\
\cline { 4 - 6 } & & & $\boldsymbol{D}_{\mathbf{T}}{ }^{\circ} \mathbf{C}$, min & $\boldsymbol{Z},{ }^{\circ} \mathbf{C}$ \\
\hline Clostridium botulinum & 7,0 & 121,1 & $0,1 \ldots 0,2$ & 10,0 \\
\hline Clostridium sporogenes & 7,0 & 121,1 & 0,6 & 10,0 \\
\hline $\begin{array}{l}\text { Bacillus (Geobacillus) } \\
\text { stearothermophilus }\end{array}$ & 7,0 & 121,1 & $2,0 \ldots 5,0$ & 12,0 \\
\hline Bacillus (Paenibacillus) polymyxa & 7,0 & 121,1 & 0,2 & 10,0 \\
\hline Bacillus (Paenibacillus) macerans & 7,0 & 121,1 & 0,2 & 10,0 \\
\hline
\end{tabular}

In experimental studies, aerobic spore-forming bacteria were isolated from 47 of the most popular canned products. Among these ones there were low acid canned vegetables (organic, and mixed, and puree). Pure cultures have been isolated from samples of sterile canned products. By their morphological, tinctorial, cultural and biochemical properties isolated microorganisms can be ascribed to subtilis-licheniformis group.

It should be noted that the food poisoning agents were detected from plant raw materials among isolated bacteria - Bacillus cereus and others. Bacillus cereus was found in $6.2 \%$ of the investigated samples of fruits, $33 \%$ of samples of carrot, $21 \%$ of samples of parsley, and up to $9.5 \%$ of the samples of canned food. 


\section{- Food technologies_—}

\section{Conclusions}

1. Group composition of epiphytic microbiota of different types of vegetable raw materials (vegetables, fruits, and berries) has been studied. Dominance of spore-forming rod-shaped organisms was detected in most samples.

2. Fungi have been found among the studied contaminants of vegetable raw materials samples. The concentration of the mycotoxin patulin, depending on the degree of spoilage fruits, was determined by the priority biological method developed by us.

3. High thermostability of spore-forming microorganisms of raw materials, including the test-cultures, was shown. This may account for their presence in canned products, cause deterioration of the organoleptic properties of foods and toxic effects on the human organism.

4. Development of modern methods of accelerated microbial detection is updated by abundance of microorganisms in the plant raw materials, and the duration and inaccurate identification of certain types of traditional methods of microbiological tests.

\section{References}

1. (2005). Discussion Paper: on strategy for setting microbial criteria for foodstuffs in Community registration, SANCO/1252/2001 [Electronic resource], European commission health \& consumer protection directorate-general, Brussel, 11, vailable at: http://ec.europa.eu/food/food/biosafety/salmonella/discussion_paper_en.pdf.

2. Blackburn Clive de W. (2006), Food spoilage microorganisms, CRC Press.Woodhead Publishing Ltd., Cambridge.

3. Miraglia M., Marvin H.J.P., Kleter G. A., Battilani P., Brera C., Coni E., Parandini A., etc. (2009), Climate change and food safety: An emerging issue with special focus on Europe, Food and chemical toxicology, 47(5), pp. 1009-1021.

4. Kleter G.A., Parandini A., Filippi L., Marvin H.J.P. (2009), Identification of potentially emerging food safety issues by analysis of reports published by the European Community's Rapid Alert System for Food and Feed (RASSF), Food and chemical toxicology, 47(5), pp. 932-950.

5. Verkhivker Y., Pylypenko L., Pylypenko Y. (2015), Microbiology, energy, packing and control of the canning production: scientific publication, LAP LAMBERT Academic Publishing, Saarbrücken.

6. Ross T., Mcmeekin T. (2002), Risk assessment and pathogen management, in: Foodborne Pathogens: Hazards, Risk Analysis and Control, McClare Cambridge: Woodhead Publishing Ltd, pp. 97-126.

7. Pylypenko L., Pylypenko Y. (2014), Byolohycheskye metody v otsenke bezopasnosty rastytelnykh pyshchevykh produktov y ynhredyentov, Yzd. «Optimum», Odesa.

8. Thomson B., Rose M. (2011), Environmental Contaminants in the light of Climate Change, Quality Assurance and safety of Crops \& Foods, 3, pp. 2-11.

9. Melngaile A., Kārkliņa D. (2013), Microbiological Risk Analysis in Catering Establishments, Proceedings of the Latvian Academy of Sciences. Section B. Natural, Exact, and Applied Sciences, 67(4-5), pp. 340-349.

10. Galynkyn V., Zaykyna N., Karcev V., Sheveleva S., Belova L., Pushkarev A. (2007), Mykrobyolohycheskye osnovy HASSP pry proyzvodstve pyshchevykh produktov, Yzd. Prospekt Nauky, Sankt-Peterburg.

11. Efymochkyna N. (2013), Mykrobyolohyia pyshchevykh produktov y sovremennye metody detektsyy patohenov, RAMN, Moscow. 
12. Lomachynskyi V.A., Helfand S. Yu.., Diakonova E.V. (2007), Bezopasnost y kachestvo produktov pererabotky plodov y ovoshchei, HNU VNYYKOP, Moscow.

13. Kaprelyants L., Pylypenko Y. (2015), The Modern Strategies of the Foodstuffs Safety and Quality Control Development, The Advanced Science Journal, 3, pp. 123-127.

14. Pylypenko Y. V. (2015), Clostridium perfringens: kharakterystyka, byolohycheskoe deistvye, yndykatsyia $\mathrm{v}$ pyshchevykh produktakh, Tekhnolohicheskii audit $i$ rezervy proizvodstva, 2/4(22), pp. 4-8.

15. Tangnif E.K., Theysf R., Mignoletf E., and etc. (2003), Patulin in domestic and imported apple-based drinks in Belgium: occurrence and exposure assessment, Food Additives and Contaminants, 20(5), pp. 482-489.

16. Luhauskas A., Stakenene Yu. (2008), Produtsyruiushchye toksyny mykromytsety na pyshchevykh produktakh rastytelnoho proyskhozhdenyia, Uspekhi meditsinskoy mikolohii, 1, pp. 152-153.

17. Barata C., Alanon P., Gutierrez-Alonso S., et al. (2008), Daphnia magna feeding bioassay as a cost effective and ecological relevant sublethal toxicity test for Environmental Risk Assessment of toxic effluents, Science of the total environment, 13, pp. 78-86.

18. König A., Kuiper H.A., Marvin H.J, et al. (2010), The SAFE FOODS framework for improved risk analysis of foods, Food Control, 21(12), pp. 1566-1587.

19. Guinebretiere M-H., Nguyen-The C. (2003), Sources of Bacillus cereus contamination in a pasteurized zucchini puree processing line, differentiated by two PCR-based methods, FEMS Microbiology Ecology, 43, pp. 207-215.

20. Efymochkyna N., Bykova Y., Batischeva S., Sheveleva S. (2012), Znachenye nekotorykh potentsyalno patohennykh mykroorhanyzmov v vozniknovenii pischevyh toksikoinfektsiy. Chast 2. Analyz y otsenka roly toksyhennykh shtammov Bacillus cereus, Voprosy pitaniya, 3, pp. 24-29.

21. Pylypenko L., Verkhivker Y., Pylypenko I. (2015), Konservyrovanie pishchevykh produktov. Mikrobyolohiya, enerhetica, kontrol: monohrafiya, BMB, Odesa. 